\title{
The tourism industry and solving the problems of patriotic education for the young generation
}

\section{La industria del turismo y la solución de los problemas de la educación patriótica para la generación joven}

\author{
Fadbir Magusovich Safin \\ Doctor of Economic Sciences, Professor, Institute of international relations \\ Kazan Federal University \\ Rafael Mirgasimoviz Valeev \\ Doctor of historical Sciences, Professor, Institute of international relations \\ Kazan Federal University
}

* Correspondence

Email: sfm195@yandex.ru 


\section{Summary}

The analysis of the current state and development of social tourism in Russia indicates the need for further research into its content and forms, aimed at introducing the historical and cultural values of our citizens, organizing their active and wholesome recreation, solving the problems of patriotic education for the country's younger generation. The paper discusses some issues of social tourism development in Russia, the role of social tourism in the preservation and development of historical and cultural heritage focuses on the need to develop measures to stimulate tourist demand, strengthen the social component of tourism in the country

Keyword: Social tourism, measures to support tourist demand, historical and cultural heritage, education

\section{Resumen}

El análisis del estado actual y el desarrollo del turismo social en Rusia indica la necesidad de una mayor investigación sobre su contenido y formas, con el objetivo de introducir los valores históricos y culturales de nuestros ciudadanos, organizar su recreación activa y saludable, resolver los problemas de la educación patriótica. para la generación más joven del país. El documento analiza algunos temas del desarrollo del turismo social en Rusia, el papel del turismo social en la preservación y el desarrollo del patrimonio histórico y cultural se centra en la necesidad de desarrollar medidas para estimular la demanda turística, fortalecer el componente social del turismo en el país.

Palabra clave: Turismo social, medidas de apoyo a la demanda turística, patrimonio histórico y cultural, educación

\section{Introduction}

One of the hot topics in tourism science and practice is the study of the state and prospects concerning social tourism development. The main social tourism goal is to make natural and artificial material and non-material values, objects of historical and cultural heritage of the country available for all interested people revealing Russia's potential for an increasing number of Russian citizens. Russia has a huge tourist and recreational potential, rich historical and cultural heritage being tangible and intangible, and complemented by natural and geographical features, traditions and customs of numerous nations and nationalities living in the country (Valeev, 2007). Implementation of social tourism goals is, on the one hand, a further development of the constitutional provisions of the Russian state, whose policy is aimed at creating the conditions for a decent life and free development of man. On the other hand, it promotes the increased involvement of historical and cultural heritage in the tourism cycle. The global trend is considered to be a growing interest in cultural and ecological tourism, which makes the Russian Federation an even more attractive tourist destination for Russian and foreign tourists. An important role belongs to tourism, and especially the social component of various types of tourism, in the preservation and development of historical and cultural values of countries, regions, specific areas, and nature reserves.

The tourism industry, negatively impacted by the COVID 19 coronavirus, is now one of the most affected sectors of economic activity. As a result, uncertainties and risks have increased significantly and the competitive environment of tourism has changed qualitatively. The forced reduction of supply and demand for tourism services has led to a collapse in the tourism market. As noted by the head of Rostourism (Russian Federal Agency for Tourism) Z. Doguzova, the total 
amount of lost revenues of the tourism industry, according to preliminary estimates, will be about 1.5 trillion rubles only for the first half of 2020. We are talking about the combined income of accommodation facilities, tour operators and agencies, as well as transport companies. At the same time, the total number of employees in the tourism industry in the Russian Federation is more than 2.5 million people, and at least 7 million people in related industries. Thus, more than 1.6 million people are at risk of dismissal or unpaid leave (https://www.atorus.ru). As a result of the crisis phenomena, a significant contraction of small and medium-sized businesses is predicted, precisely in the sphere to which the tourism industry enterprises mainly belong. According to various estimates, taking into account the duration of tourist flow recovery, up to 30 percent of tourism firms will have to leave the tourism market over the next 6 months. The number of tourism firms in the country reached 14,000 by 2020 . According to expert forecasts after the crisis is over, no more than 8-9 thousand tourist organizations will remain and continue their economic activity. At the same time, there is a pent-up demand for travel, leisure, business and other trips within the country and abroad. However, the pent-up demand for tourism services will not be realised and recovered in a short time period; quick changes are not expected; according to various expert estimates it will take from one and a half to three years for a full recovery. Estimates of key industry players (federal Russian and international hotel chains, tour operators, restaurant and entertainment centres, owners of sports infrastructure, entities in the children's tourism segment) are more optimistic. In their opinion, the beginning of business recovery is predicted not earlier than in six months from the date of lifting the existing restrictions, and the beginning of export tourism recovery and return to the pre-crisis volumes of inbound tourist flow would come not earlier than in the middle of 2021 (https://www.atorus.ru). Moreover, the restored format of the tourism industry will differ significantly from those parameters that existed before. There are several reasons for this. Firstly, it is difficult to predict the timing of a coronavirus pandemic, which will differ from country to country in terms of timing and form of completion. Hence the uncertainty and risks of states lifting restrictions on tourism occur; secondly, there has been a climate of anxiety and fear, a high degree of uncertainty that is beyond the control of any individual but has a strong emotional impact on individuals. Thirdly, there has been a reduction in income for a large part of the population. The solution of these and other problems requires both urgent tactical and strategic measures to bring the tourism industry out of crisis, to create new forms of organizing activities, opening new directions, more active reanimation of existing types of tourism. Currently, measures to support the tourism industry are being implemented at the level of federal authorities and regions. Apart from tax deferral, interest-free loan for salary payment, deferral of rent payments, protection from bankruptcy and some others, special support measures are envisaged for the tourism sphere, which to a certain extent will help to lead the tourism industry out of stagnation. These and some other factors have now actualized the need to study the state and prospects of social tourism development.

\section{Methods}

This paper presents a theoretical-methodological and system analysis of social tourism as a multidimensional socio-economic phenomenon. The main purpose of the study is to analyse the current state of social tourism and to work out proposals for its further development.

\section{Results and Discussion}

The social tourism concept is widely used in tourism science and practice. A wide range of issues devoted to the state and development of social tourism has been studied in the scientific literature. The studies by Azar V.I., Zorin I.V., Kvartalny V.A., Birzhakov M.B., Aleksandrova A.Y., Kaverina T.V., Putrik Y.S. and some others consider the essential aspects of social tourism, its conceptual apparatus, structural elements, trends, and some parameters of social tourist product. They note that social tourism, which is understood as tourism aimed at persons (restoration of their physical, mental and intellectual forces) accessible to all segments of the population, is able to realize the social antinomy of tourism. It is the parameters of accessibility and real possibilities of its maximisation in particular conditions and define that minimally necessary set of social tourism services which in aggregate makes social tourism product (Azar \& Tumanov, 1998). In our opinion, it is possible to agree as a whole with the definition offered by M. B. Birzhakov that 
social tourism is a type of tourism subsidized by the funds allocated for social needs, in order to create conditions for travel to schoolchildren, youth, pensioners, veterans of war and labour and other citizens, to whom the state, government and non-government funds and other charitable organizations provide social support (Birzhakov, 2011). We believe that a little clarification is required. We think, social tourism cannot be a type of tourism. Any kind of tourism for children, cultural and educational, therapeutic, ecological, rural, etc. purposes, the expenses for which are fully or partially subsidized to tourists from various financial sources, not only from the state, but also from enterprises of various forms of ownership in the form of social package, other stimulating measures and forms, could be social tourism. We believe that the concept of social tourism includes accessibility and mass consumption of tourist services by an unlimited number of people. Therefore, any kind of tourism, perhaps, with a rare exception, may have elements of social tourism. As A.Y. Aleksandrova fairly observes, "the social tourism concept rests on three fundamental principles: providing recreation for all and every member of society; subsidizing tourism for the poor; active participation of central governmental, municipal, public and commercial structures in its development" (Aleksandrova, 2004). We believe that at the present time, this approach is the most reasonable and demanded to understand the essence and boundaries of social tourism.

The basic principles of social tourism were stated in the Manila Declaration on World Tourism, which notes that "social tourism is a goal to which society should aspire for the benefit of less well-off citizens in the exercise of their right to rest" (http://docs.cntd.ru). Such conceptual approach accepted in the Manila Declaration substantiates urgency and necessity of researching the problems on social tourism development. The retrospective analysis of the experience concerning social tourism development in our country confirms the fact that one of the world's most advanced social tourism organization systems was created in the USSR. As fairly noted by O. Strizhova and N. Prazdnikova, the Soviet state considered social tourism as an integral part of its social policy. The social tourism system of the Soviet type was based on universal equal access to tourist services. The social component consisted in the fact that through the trade union committees in enterprises and institutions, the recreation of employees and their families was partially or fully paid for, i.e. a subsidy was made at the expense of social insurance and budgetary sources (Strizhova \& Prazdnikova, 2020). The social tourism system being existed in the Soviet Union disintegrated with the country's transition to the market; a new effective social tourism system adapted to market conditions has not yet been formed. At the same time, the above does not mean that the social tourism organization problems are forgotten or neglected in Russia. The Federal Law dated 24 November 1996 № 132-FZ "On the Fundamentals of Tourism Activities in the Russian Federation" established that "social tourism is tourism fully or partially carried out at the expense of budgetary funds, state extra-budgetary funds (including funds allocated under the state social assistance), as well as funds of employers" (https://legalacts.ru). Twenty-odd years ago, an attempt was made to develop and adopt a special Federal Law "On Social Tourism". The project aimed at implementing the Federal Law "On the Fundamentals of Tourism Activities in the Russian Federation» was designed to define the legal and organizational framework, and to establish sources of funding for social tourism. According to the draft law's authors, social tourism is travels and other tourist trips for recreation, health, introduction to the natural and cultural and historical heritage which services are sold to the citizens of the Russian Federation at a social tour price or carried out independently, or subsidized from the funds allocated by the state for social needs (http://asozd2.duma.gov.ru). However, the social tourism definition proposed in the draft, in our opinion, is not quite correct and requires its clarification. Firstly, social tourism financing sources were not proposed in the draft; secondly, a specific categorical circle of people entitled to perform a social tour was not defined; thirdly, basic standards of tour accessibility were blurred. This draft law has remained an unimplemented project.

A number of documents, in particular the Strategy for Tourism Development in the Russian Federation for the period until 2020 dated 31 May 2014, highlighted the need to strengthen the social role of tourism, including the development of social, therapeutic, children, 
teenage and youth tourism among the priorities. The Strategy noted that the social role of tourism is manifested in its recreational, educating and upbringing function, and also that the social tourism development with the involvement of budgetary and non-budgetary sources of funding is now one of the main directions to realise the needs of socially disadvantaged groups in the Russian Federation and to increase the availability of tourism services (http://docs.cntd.ru). The actualization of this approach will contribute to the growth of mass domestic tourism, the active involvement of historical and cultural, natural and artificial objects in the tourist resources.

In 2015 the Federation Council Committee on Social Policy made a fairly successful attempt to analyse the problems of social tourism development in the country in a comprehensive way, involving a wide range of practitioners and the scientific community. The conference proceedings noted that today we can confidently say that social tourism is an issue of national importance. However, we have to note that the regulatory framework concerning social tourism in Russia still contains only separate norms governing relations in this area, which makes urgent the work on its comprehensive legal support (http://www.rmat.ru). The current Strategy for Tourism Development in the Russian Federation for the period up to 2035 (https://www.russiatourism.ru) also declares the need to strengthen the social role of tourism and ensure accessibility of tourism services, recreation and health for the citizens of the Russian Federation, and implements the Strategy aims to increase the social and economic role of tourism in the development of the country and some subjects of the Russian Federation. However, this document does not single out the social tourism institution as was done in the previous Strategy for Tourism Development in the Russian Federation for the period up to 2020. Therefore, we believe that in order to effectively develop the social tourism institution, it is necessary to amend the Federal Law dated November 24, 1996 "On the Fundamentals of Tourism Activities in the Russian Federation" and adopt other normative legal acts.

In modern Russia, the social tourism condition and development requires not just adjustments, but a fundamental change in the system of its organization. The social tourism development in our country is constrained by a number of factors. The demand for the tourism product in the Russian Federation is considerably limited by its high cost, which, first of all, is caused by significant costs of tourists' transportation. With the high cost of transportation, many attractions of our homeland remain inaccessible for a significant number of the country's population. Another hindering factor for tourism development is the lag in the pace of modernization and creation of engineering infrastructure and tourist infrastructure, on one side, from the rate of growth of tourist interest in the territory, on the other side. Thirdly, it is the low income of a significant part of the able-bodied Russian population limiting travel expenses. This category also includes schoolchildren, pensioners and people with disabilities. With the on-going wealth stratification, decreasing incomes of the population, when almost 20 million citizens of Russia are recognized poor, and half of the country's residents have monthly incomes below 25 thousand roubles, so travels for a significant number of Russians is becoming unaffordable. According to various sources, the domestic tourist flow in Russia in 2019 was about 60 million people. However, this figure needs to be adjusted downwards, as a certain part of our country's population travels several times a year, some once in 2-3 years. Taking this into account, the number of travellers in Russia, according to our calculations, is actually 25-30 million people per year. Thus, practically more than 100 million Russians cannot afford to travel: they can not see and experience directly the historical and cultural, and natural riches, material and non-material heritage of the homeland. Currently, this situation is exacerbated by the fact that the recessionary processes in the economy, accompanied by rising unemployment, increasing proportion of poor people mean a quantitative and qualitative decrease in the demand for tourist travel, narrowing the demand for tourism. Social tourism has an important role to play in reversing the trend from negative to positive. Social tourism is one of the necessary tools for tourism planning that promotes the integrated use of tourist and recreational potential, of historical and cultural heritage of territories, and also for effective intercultural and inter-regional communication, the actualization of the patriotic education forming cultural and moral potential of the Russian Federation regions.

\section{Summary}


Social tourism is an effective tool for the restoration and development of the tourism industry and the preservation and further development of the historical and cultural heritage. The need for more active use of social tourism as a key direction in the preservation of cultural heritage is now recognised as extremely urgent. We believe that the types and forms of social tourism are plural, not limited to a specific framework; the social component can be present in any tourist product. Any kind of tourism, namely, children, cultural and cognitive, therapeutic, ecological, rural, etc., expenses for which are fully or partially subsidized to tourists from various financial sources, using various forms of social package, refers to social tourism. The dominant trends for the near future are focusing on domestic tourism and economy tours, and also reconfiguring and changing travel time, etc. The actualization of domestic tourism development in Russia should be accompanied by the expansion of social tourism support, which primarily requires an impetus from the state, including a variety of measures of financial, economic, organizational nature, development of targeted social programs, projects at the federal and regional levels, involving business structures, and a number of other measures. Here the task of a new vision concerning the social component of tourism arises, in other words, more active social tourism development.

\section{Conclusions}

The analysis of the current state and development of social tourism in Russia indicates the need for further research into its content and forms, aimed at introducing the historical and cultural values of our citizens, organizing their active and wholesome recreation, solving the problems of patriotic education for the country's younger generation. The tourism industry will be restored according to various scenarios. But in any case it will not happen overnight, in a short period. Some areas will require several months, some years, depending on external and internal factors, personal factor, and staff competence. First of all, the interaction format for communicating between producers and consumers of tourism services, transaction costs, the configuration of competitive forces in the travel industry market will change, because the active use of Internet technologies, the quantitative and qualitative expansion of mobile applications, online shopping, author and amateur tours cannot but bring qualitative changes in the activities of travel companies and the behaviour of touristic service consumers. It is possible to make tourist trips more individual, develop auto-tourism, as well as to form such type of tourism as authorial tourism. The support of tourist industry enterprises and tourist infrastructure implemented at different levels of power does not and cannot mean the quantitative growth of demand for tourist products. The measures taken are primarily aimed at preserving the tourism industry enterprises. Therefore, stimulating demand for tourist travel is required in addition to supporting tourism industry enterprises. All the more so, because the multiplier effect of the tourism industry will allow other related sectors to be involved in the recovery process. First of all, it should be about stimulating domestic tourism: regional and interregional. It is in this aspect that it is necessary to develop state and business support, so that objects of tangible and intangible heritage, historical, cultural and spiritual riches of the country would be accessible to every Russian citizen.

\section{Acknowledgements}

The work is performed according to the Russian Government Program of Competitive Growth of Kazan Federal University.

\section{References.}

Aleksandrova, A.Yu. (2004). International tourism. Moscow: Aspect Press, - 263p.

Azar, V.I., Tumanov, S.Yu. (1998). Economics of the tourism market. - Moscow: IPG State Service,. - 239 p.; Aleksandrova A.Yu. Structure of the tourist market. - Moscow: Presssolo, 2005. - 186 p.; Birzhakov M.B. Introduction to tourism: Textbook. - 6-th edition translated and enlarged, SPb: "Publishing house Gerda", 2004. - 448 p.; Zorin I.V., 
Kaverina T.P., Kvartalnov V.A. Tourism as an activity: Textbook. Moscow: Finance and Statistics. 2005.-288 p.; History of tourism. (Responsible editor - Putrik Y.S.) Moscow: Federal Agency for Tourism, 2014. - $256 \mathrm{p}$.

Birzhakov, M. B. (2011). Special types of tourism. Saint Petersburg: SPbGEEU.

Draft Federal Law "On Social Tourism". http://asozd2.duma.gov.ru/arhiv\%5Ca_dz_3.nsf/ByID/3B6260342B148D0B43256EF3004 AF8D9?OpenDocument. Access date 09.02.2020.

Federal Law "On the Fundamentals of Tourism Activities in the Russian Federation" dated 24.11.1996 No. 132-FZ (revised on 02.12.2019). - https://legalacts.ru/doc/federalnyizakon-ot-24111996-n-132-fz-ob. Access date 06.02.2020.

https://www.atorus.ru/news/press-centre/new/51233.html. Access date 11.05.2020

Manila Declaration on Tourism. Adopted by the World Tourism Conference in Manila, Philippines, 27 September - 10 October 1980. http://docs.cntd.ru/document/901813698. Access date 06.02.2020.

Social tourism as a tool to improve the quality of life of the population and the potential for socioeconomic development of the regions in the Russian Federation: collection of articles and materials of the correspondence All-Russian scientific-practical conference / Edited by O.A. Koptseva. - M: PKTs Alteks LLC, 2015. http://www.rmat.ru/wyswyg/file/library/21122015_soctur_sbornik.pdf. Access date 10.04.2020.

Strategy for Tourism Development in the Russian Federation for the period until 2020, dated 31 May 2014. No. 941-r (version of 21.03.2019) http://docs.cntd.ru/document/420200177. Access date 10.04.2020.

Strategy for Tourism Development in the Russian Federation until 2035, dated 20 September 2019 No. 2129-r. $\quad$ https://www.russiatourism.ru/upload/iblock/298/ Strategiya\%20razvitiya\%20turizma\%20na\%20period\%20do\%202035\%20goda.pdf. Access date 10.04.2020

Strizhova, O.S., Prazdnikova, N.N. (2020). Social tourism in Russia: problems and prospects for development. https://cyberleninka.ru/article/n/sotsialnyy-turizm-v-rossii-problemy-iperspektivy-razvitiya. Access date 09.02.2020г.

Valeev, R.M. (2007). Historical and Cultural Heritage of the Republic of Tatarstan: Trends of Development and Experience of Research, Preservation, Restoration and Use in the Last Quarter of XX Century / R. M. Valeev; Ministry of Culture of the Republic of Tatarstan, Kazan State University [etc.]. - Kazan: Idel-Press,. - 319 p.; Garifullina R.S., Safin F.M. Tourist and recreational potential of territories: monograph.-Editorial-publishing centre "Shkola".-2019.-332; Galimov Sh., Galimova L.I. The objects of intangible culture of Tatarstan in the development of regional tourism. Modern problems of service and tourism. 2016. Vol. 10. № 3. P. 86-90.

Brief information about the authors:

Rafael Mirgasimovich Valeev, Doctor of Historical Sciences, Professor, Head of the World Cultural Heritage Department in the Institute of International Relations at Kazan Federal University; acknowledged expert in the field of tangible and intangible cultural heritage in the Russian Federation, UNESCO expert.

Fadbir Magusovich Safin, Doctor of Economics, Professor, World Cultural Heritage Department in the Institute of International Relations at Kazan Federal University; specializes in theoretical problems of tourism science. 